\title{
PERAN PERS PADA MASA ORDE BARU DI PONTIANAK TAHUN 1966-1974
}

\author{
Uti Mohammad Wildan ${ }^{1}$, Sahid Hidayat ${ }^{2}$ \\ ${ }^{1,2}$ Pendidikan Sejarah, IKIP-PGRI Pontianak \\ Email: ${ }^{1}$ will602uti@gmail.com
}

\begin{abstract}
Abstrak
Tujuan Penelitian ini adalah untuk melihat peran pers pada masa Orde Baru di Pontianak tahun 1966-1974. Metode penelitian yang digunakan adalah metod penelitian sejarah dengan langkah-langkah heuristik (Pengumpulan sumber), verifikasi (Kritik sumber), interpretasi dan historiografi. Hasil penelitian menunjukkan bahwa pers sebagai bagian dari sistem komunikasi, menempati posisi strategis dalam masyarakat Pontianak. Pers berperan sebagai jembatan komunikasi timbal balik antara pemerintah dan masyarakat, serta masyarakat dengan masyarakat sendiri. Sejarah pertumbuhan pers di Pontianak telah menempatkan kekhususan posisi dan ciri-ciri khas yang melekat pada pers sebagai lembaga kemasyarakatan. Pers mempunyai peranan dalam pengawasan pembangunan nasional sebagai realisasi dari tanggung jawab sosial sebagai alat kontrol sosial. Pemerintahan Orde membutuhkan kestabilan umum dalam menjalankan roda kepemerintahan dan menjaga wibawa negara.Pada awal masa orde baru pers di Pontianak memiliki peranan membantu pemerintah dalam menertipkan gejolak serta peristiwa yang terjadi di Pontianak. Pers terlihat sebagai satu tindakan nyata dalam propaganda pemerintah. Propaganda-propaganda pembangunan- pembangunan yang dilakukan pemerintah mewarnai tajuk berita yang dimuat.
\end{abstract}

Kata Kunci: pers, Orde Baru, Pontianak

\begin{abstract}
The aim of this research is to look the role of pers in the new order in Pontianak, from 1966-1974. The methods of this research is a historical research includes four stages; heuristic, verification, interpretation, and historioghraphy. The results of this research show if the pers is an essential part of the communication, have a strategic position in Pontianak society. The pers is a connected from government and society. The history of pers in Pontianak was putted in central position with a special characteristic as an institution of society. The pers have a role as social control. The new order needs the stability of nation to maintain the continuity of governement. Pers is one tools of government propaganda. The propagandas of development we can see in the news printed.
\end{abstract}

Keywords: press, Orde Baru, Pontianak

\section{PENDAHULUAN}

Istilah pers atau press berasal dari istilah Latin pressus artinya adalah tekanan, tertekan, terhimpit, padat. Pers dalam kosakata Indonesia berasal dari bahasa Belanda yang mempunyai arti sama dengan bahasa inggris "press" sebagai sebutan untuk alat cetak. Keberadaan pers pada terjemahan ini pada umumnya adalah sebagai media penghimpit atau penekan dalam masyarakat. Makna lebih tegasnya adalah dalam fungsinya sebagai kontrol sosial. Di sini yang juga tidak 
jarang menjadi sebuah media penekanan terhadap kebijakan tertentu yang dinilai tidak dijalankan sebagaimana mestinya oleh pihak yang seharusnya secara lurus dapat menjalankannya. (Irma Syahriar, 2015: 29).

Pers dalam menjalankan fungsi dan peranya, memiliki asas atau landasan kemerdekaan sebagai wujud kedaulatan rakyat berasas prinsip-prinsip demokrasi, keadilan, dan supremasi hukum. Asas ini termaktub dalam UU No. 40/1999 tentang Pers dan SK Dewan Pers 79/1974. Yang menegaskan bahwa Pers Nasional, berpijak kepada enam landasan. Pers memiliki kedudukasn yang sangat penting dalam pembangunan suatau bangsa. Pers merupakan pilar keempat demokrasi setelah legislatif, eksekutif dan yudikatif. Kerena itu, pers meiliki pengaruh yang amat besar terhadap masyarakat. Pers berkontribusi dalam perubahan budaya masyarakat. Kuatnya pengaruh pers ini acapkali dimanfaatkan oleh pemerintah untuk mengendalikan suatu kondisi. Pers dijadikan alat hegemoni kekuasaan, legitimasi masa, dan pencitraan. Penguasa kerap berusaha mengendalikan pers agar pilar keempat ini tidak sampai menyebarkan opini yang dapat merusak citra pemerintah (Teguh Trianton, 2016: 24).

Perkembanganya wajah Pers Indonesia sendiri mengalami pergantian dari waktu ke waktu. Dari masa penjajahan belanda, masukanya jepang serta masa sebelum kemerdekaan, Pada Masa Orde Lama, tepatnya pada tahun 1960, pada era ini pemerintah memposisikan pers sebagai alat revolusi. Pemerintah menerapkan kontrol yang sangat ketat terhadap media masa.aturan ini diperkuat dengan TAB MPR No 11 tahun 1960 tentang peneragan masa. Kemudian diberlakukanya Surat izin terbit (SIT). Barulah Sejak lahirnya TAB MPR No. 32 tanggal 12 Desember 1966, tepatnya Pada awal kepemimpinan orde baru, terdapat sebuah kemajuan dalam hal kebebasan pers dengan terbitnya TAP MPR No. 32 tanggal 12 Desember 1966,kehidupan pers kembali bangkit. 4 TAP MPR tersebut menjamin kebebasan pers dengan ditiadakannya sensor dan pembredelan, serta menyatakan membuang jauh praktik demokrasi terpimpin diganti dengan demokrasi Pansasila, hal ini mendapat sambutan positif dari semua tokoh dan kalangan, sehingga lahirlah istilah pers Pancasila. Namun, ketentuan ini 
“dimandulkan" dengan adanya pasal dalam undang-undang yang sama yang menyatakan masih diperlukannya Surat Izin Terbit atau SIT.

Kebebasan pers pada masa itu pun mendapat berbagai tekanan dari pemerintah. Tidak ada kebebasan dalam menerbitkan berita-berita miring seputar pemerintah. Bila ada maka media masa tersebut akan mendapatkan peringatan keras dari pemerintah yang tentunya akan mengancam penerbitannya. Akibatnya, fungsi pers sebagai kontrol sosial mengalami pembatasan. Jika pers berani mengkritisi wilayah kekuasaan maka sama sekali tidak dibenarkan dan diberedel. Puncanya terjadi akibat pristiwa 15 Januari 1974 (Malari) pemerintah memberedel sebelas penerbitan pers umum, bahkan Surat kabar mingguan mahasiswa Indonesia (Teguh Trianton, 2016:12-15).

Pers umumnya tunduk pada sistem pers yang berlaku dimana sistem itu hidup, sementara sistem pers itu sendiri tunduk pada sistem politik pemerintah yang ada. Bersama dengan lembaga kemasyarakatan lainnya, pers berada dalam keteterikatan organisasi yang bernama Negara, oleh karenanya pers dipengaruhi bahkan ditentukan oleh falsafah dan sistem politik Negara dimana pers situ berada. Perkembangan pers di Pontianak sendiri banyak sekali mengalami perkembangan dari masa hindia Belanda, Jepang, masa sebelum kemerdekaan hingga orde lama dan orde baru. Setiap pers dari masa ke masa memiliki karakteristiknya sendiri. Dari adanya kebebasan hingga dibredelnya kebebasan pers tersebut. Khusus pada masa orde baru, Pres mendapatkan tantanganya sendiri. Dengan menjadi perpanjangan tangan Pemerintah. Pers menjadi konformis Govermant yang tidak mendapatkan kebebasan serta tidak lagi menjadi penyalur informasi dari masyarakat ke pemerintah melaikan hanya penyalur informasi pemerintah ke masyarakat saja.

\section{METODE}

Metode penelitian merupakan suatu proses dengan cara-cara atau langkahlangkah yang terstruktur dengan tujuan untuk mendapatkan sesuatu yang dapat dikembangkan dan dibuktikan dengan data yang valid. Metode penelitian yang 
digunakan adalah metode penelitian historis yang terdari dari: Heuristik, verifikasi, interpretasi dan historiografi.

Tahapan pertama Heuristik yang berasal dari bahasa Yunani yaitu "heuriskein" yang berarti mencari atau menemukan. Pengumpulan sumber sejarah dimaksudkan untuk membandingkan sebuah evidensi dengan sumbersumber yang tersedia di lapangan. Merujuk pada apa yang dikatakan oleh Kuntowijoyo, peneliti berusaha semaksimal mungkin mengumpulakan sumber sebanyak-banyaknya. Sumber yang dikumpulakan dalam peneltian ini dibagi menjad dua, yaitu sumber primer dan sumber sekunder.

Tahap kedua dalam metodologi sejarah adalah kritik Sumber, bertujuan untuk menganalisis kebenaran atau keaslian sumber berupa dokumen maupun arsip, kegiatan kritik sumber ini adapun fungsi dan tujuan dari kritik sumber adalah untuk membedakan apa yang benar, apa yang tidak salah (palsu), apa yang mungkin dan apa yang meragukan atau mustahil, Helius Sjamsudin (2012: 103). Kritik terdiri dari kritik ekstern dan intern. Sumber- sumber yang berupa bukubuku kepustakaan dilihat isinya relevan dengan permasalahan yang dikaji serta dapat atau tidak akan kebenaran dari data tersebut.hal ini dilakukan karena ingin memperoleh informasi dengan nilai pembuktian dari isi atau data sumber tersebut masih relevan atau tidak. Pada tahap kritik intern untuk mengkritisi hasil wawancara, yaitu dengan membandingkan isi data yang peneliti peroleh dari lapangan berupa hasil wawancara dari informan satu dengan informan lainnya. Perbandingan jawaban tersebut bertujuan untuk mempermudah penulis dalam menyimpulkan mengenai keterangan yang diberikan oleh para informan tersebut akan kebenaran jawaban atas pertanyaan yang diajukan. Hal ini dilakukan karena ingin memperoleh jawaban dengan nilai pembuktian dari isi atau sumber tersebut masih relevan atau tidak.

Tahapan ketiga Interpretasi atau penafsiran adalah proses komunikasi melalui lisan atau gerakan antara dua atau lebih pembicara yang tak dapat menggunakan simbol-simbol yang sama, baik secara simultan (dikenal sebagai interpretasi simultan) atau berurutan (dikenal sebagai interpretasi berurutan). Dalam bukunya Kuntowijoyo (2008: 2-3) menjelaskan mengenai interpretasi, 
yang mengungkap bahwa sejarah: menafsirkan, memahami, mengerti. Tugas interpretasi adalah memberikan penafsiran dalam kerangka memugar (memperbaiki kembali) suatu rekontruksi masa lampau. Kegiatan ini adalah berusaha menafsirkan terhadap fakta sejarah hasil dari kritik sumber yang dipilih dan dirangkai secara kronologis, rasional, faktual dan kualitas. Interpretasi dilakukan dengan cara merangkai data-data atau fakta-fakta satu sama lain sehingga menjadi rangkaian yang logis yang menunjukkan keserasian antara satu sama lainnya secara berurutan.

Tahapan keempat historiografi, cara untuk merekontruksi gambaran masa lampau berdasarkan data yang diperoleh, Kuntowijoyo (2013:80-81). Memasuki tahap penulisan sejarah, menguras seluruh daya pikiran, keterampilan dalam penggunaan kutipan dan catatan tertentu. Tetapi yang terutama penggunaan pikiran kritis dan analisisnya karena pada akhirnya harus menghasilkan suatu sintesis dari seluruh hasil penelitiannya atau penemuannya itu dalam suatu peulisan yang utuh disebut dengan historiografi, Helius Sjamsuddin (2012: 121).

\section{HASIL DAN PEMBAHASAN}

\section{Sikap Pemerintah Orde Baru terhadap Pers}

Pada awal pemerintahan Orde Baru pers sempat mengalami masa kebebasan dengan dikeluarkannya TAP MPRS RI No XXXII/MPRS/1966 tentang Pembinaan Pers memberi pengakuan kebebasan hak setiap warga negara untuk mengeluarkan pendapat dan pikiran melalui pers. Tap MPRS ini menjadi dasar perumusan UU No 11/1966 yang menyatakan bahwa Kebebasan Pers Indonesia adalah kebebasan untuk menyatakan serta menegakan kebenaran daan keadilan, bukan kebebasan dalam arti liberalisme (Sinung Utami, 2012: 3).

Kebijakan Orde baru mendukung sepenuhnya pers Pancasila untuk berperan kembali dalam masyarakat menyuarakan aspirasi rakyat yang sebelumnya dibungkam oleh Soekarno (masa orde lama). Pada periode awal Orde Baru, persepsi sikap dan perlakuan penguasa terhadap pers, telah berubah secara berarti. Pemerintah Orde Baru memandang dan memperlakukan pers sebagai Partner of power-nya untuk membantu pemeritah menstabilkan negara, serta alat 
konsolidasi kekuasaan Presiden Soeharto untuk membangun pemerintahan Orde Baru secara penuh (Satrio Saptohadi, 2011:127). Di Pontianak, pemerintah pada masa orde baru juga memperhatikan kesejahteraan lembaga pers saat itu, dengan memberikan subsidi terhadap lembaga pers resmi yang disertai Surat Izin Usaha Penerbitan (SIUP).

Tidak berhenti di sana saja, sikap pemerintah pada saat itu juga dianggap ada keberpihakan terhadap kehiduan pers, contoh seperti pembinaan lembaga dan wartawan. Melalui PWI (Persatuan Wartawan Indonesia) dan Deperteman Penerangan pemerintah memberikan pelatihan-pelatihan kewartawanan yang langsung di bina oleh wartawan senior pada masa itu, seperti Rosehan Anwar dan Gunawan Mohammad. Khusus untuk pimpinan redaksi pada saat itu diwajibkan untuk mengikuti P4 (Pedoman Penghayatan dan Pengamalan Pancasila) Nasional yang di bina langsung oleh Angkatan Darat atau ABRI.

\section{Peranan Pers di Pontianak}

Dalam perkembangannya pers di Pontianak telah mengalami proses cukup panjang. Pada masa Orde Baru tahun 1966-1974 peran pers dapat di karakteristikan menjadi beberapa periode:

Tabel 1. Karakteristik Peran Pers di Pontianak Pada Masa Orde Baru

\begin{tabular}{|c|l|}
\hline Tahun & \multicolumn{1}{|c|}{ Keterangan } \\
\hline 1966-1968 & $\begin{array}{l}\text { Pers di Pontianak aktif mengamankan dan membantu pemerintah } \\
\text { dalam menertipkan gejolak serta peristiwa yang ada dalam } \\
\text { masyarakat. }\end{array}$ \\
\hline 1969-1970 & $\begin{array}{l}\text { Pers di Pontianak disibukan dengan kegitan pemberitaan tentang } \\
\text { pembangunan- pembangunan yang dilakukan oleh pemerintah. }\end{array}$ \\
\hline 1971-1974 & Pers di Pontianak sudah kearah komersil. \\
\hline
\end{tabular}

Ketimpangan pembangunan ekonomi yang dilahirkan zaman Orde Baru juga membuat kepemilikan media cetak dan sebaran sirkulasinya terpusat di kotakota besar. Tidak salah apabila perkembangan awal pers di kalimanatan barat di mulai dari Pontianak. Dengan kondisi media cetak yang terpusat itu, sulit diharapkan perannya untuk menyebarkan gagasan kesadaran nasional secara merata. Media masa di masa Orde Baru diarahkan untuk mendukung program 
pembangunan pemerintah. Dalam menyebarkan gagasan kesadaran nasional, yang berperan para pemimpin formal dan informal, serta saluran antarpribadi lain di pelosok-pelosok. Dengan pengontrolan arus informasi dari pusat, dapat diperkirakan komunikasi pembangunan lebih bersifat monologis ketimbang dialogis, sehingga aspirasiaspirasi lokal menjadi kurang terserap (Retor AW Kaligis, 2011:88).

Media lokal memaikan peran Yang tidak bisa dianggap sepele dalam peekembangan kehidupan pers di Indonesia. Pola memusat dalam narasi besar pemberitaan seiring dengan kuatnya posisi pulau jawa (terutama Jakarta) sebagai sumber berita memuat dinamika media lokal jarang terbaca dalam memanajeman pemberitaan tidak kalah apabila dibandingkan dengan Jakarta dan kota-kota lain di jawa sebagai sentral wacana media. (Muhamma Sulhan, 2006: 319). Tidak bisa dipungkiri walaupun demikian pers tetap memiliki peran yang sangat penting di suatu negara. Tanpa pers, tidak ada informasi yang tersalurkan baik dari rakyat ke pemerintahnya maupun sebaliknya. Singkat kata, pers memiliki posisi tawar yang tidak bisa diremehkan. Pers berfungsi sebagai pemikir dan penguji konsep-konsep yang diterapkan pada setiap kebijakan.

Pada masa orde baru, pers di Pontianak bisa dikatakan terbatas dalam menjalankan fungsinya dikarenakan mereka hanya melakukan penyampaian informasi lebih banyak dari pemerintah kepada masyarakat, sedikit penyampaian informasi yang dilakukan dari masyarakat kepada pemerintah, penyampaian informasi itu pun jangan sampai menyinggung pemerintah, apabila pemeritah kurang berkenan dengan pemberitaan maka harus berhati-hatilah media cetak tersebut dan wartawannya. Mereka akan di panggil dan di minta pertanggung jawbannya berkenaan dengan berita yang di buat.

Walaupun ada Undang-undang Pokok Pers Nomor 11 Tahun 1966 yang menjamin kebebasan pers. Tetapi sebetulnya Undang-undang ini hanya semacam cek kosong di dalam prakteknya tidak berjalan seperti yang tertulis. Keberadaan pers diawasi secara ketat oleh pemerintah di bawah naungan Departemen Penerangan. Hal ini dilakukan untuk mengantisipasi hal - hal buruk di dalam pemerintahan orde baru sampai di telinga masyarakat. Aspirasi masyarakat untuk 
pemerintah tetap dapat tersalurkan. Akan tetapi pemberitaan yang dimuat tidak berhubungan dengan masalah-masalah yang membuat pemerintahan tidak tersudut olehnya. Dalam kehidupan Pers di Pontianak mereka tetap dapat menjalankan perannya sebagai komunikator dari pemerintah ke masyarakat, dan sebaliknya.

Setelah berjalan selama satu tahun, pemerintah orde baru membuat peraturan kembali untuk mengatur kehidupan pers dengan menerbitkan UU No 4 tahun 1967 sebagai penambahan UU no 11/1966, Undang-undang baru ini mengatur mengenai "Pengamanan terhadap barang-barang cetakan yang isinya dapat mengganggu ketertiban umum, khususnya mengenai bulletin-bulletin, suratsurat kabar harian, majalah-majalah dan penerbitan-penerbitan berkala" (UU No 4 Th 1967 pasal 2). Implikasi intervensi kepentingan pemerintah juga berakibat buruk pada independensi media. Saat itu, tidak banyak pers yang mempunyai sikap independen dan kritis terhadap pemerintah, dengan berbagai cara pemerintah selalu berupaya mengontol pers secara represif. Pemerintah tidak hanya mempraktekkan "Budaya telepon" untuk menteror kebebasan, tetapi juga melakukan pemberedelan penerbitan, pemberhentian pemasokan kertas koran hingga menghilangkan nyawa wartawan, merupakan konsekwensi yang harus ditanggung manakala lembaga pers menerbitkan berita serta wartawan yang meliput pemberitaan mengkritik dan bertentangan dengan kebijakan pemerintah.

Pers di Pontianak, jarang sekali mengalami pembredelan oleh pemerintah Orde Baru atau wartawan yang ditangkap karena pemberitaannya yang tergolong "lunak" terhadap penguasa. Akan tetapi bukan berarti tidak ada yang berani pada saat itu mengkritisi pemerintah orde baru. Dari segelintir media yang memilih untuk menutup mata melihat permasalahan yang sumbang masih ada beberapa wartawan dan media cetak yang berani mengkritisi pemerintah saat itu. Kehidupan pers di Pontianak sepanjang sejarah Orde Baru tidak terlepas dari berbagai kebijakan yang dikeluarkan oleh pemerintah pusat. Aturan dan kebijakan itu cenderung represif dalam mengendalikan pers. Sehingga pada saat itu banyak media yang tergolong cendrung memberitakan segala sesuatu yang ringan dan tidak tergolong dalam berita yang panas. 
Pada tahun 1969 di Pontianak, dikenal sebuah konsep yang dinamakan Jurnalisme Pembangunan. Konsep ini menegaskan bahwa sebaiknya pemberitaan jurnalistik menampilkan pembangunan-pembangunan yang dilakukan oleh pemerintah, terutama oleh pimpinan pemerintah. Pers juga dinyatakan sebagai salah satu media pendukung keberhasilan pembangunan. Masuk pada tahun 1966, didengungkan tentang kebebasan pers yang bertangung jawab, Namun pada kenyataanya, Kelangsungan lembaga pers pada tahun 1978 memalui terbitnya TAP MPR RI No. IV/MPR/1978, sejak itu kehidupan pers ditentukan oleh pemerintah dengan diberlakukannya Surat Izin Usaha Penerbitan (SIUP) oleh departemen penerangan (Sinung Utami, 2012: 3).

Dalam perkembangan pers di Pontianak pada masa orde baru tercatat beberapa media yang sempat mewarnai kehidupan dan dinamika pers yang ada di Pontianak.

Tabel 2. Daftar Media Cetak Yang Ada di Pontianak dalam kurun waktu 19661974

\begin{tabular}{|l|c|c|l|}
\hline \multicolumn{1}{|c|}{ Media Cetak } & Jenis & \multicolumn{1}{|c|}{$\begin{array}{c}\text { Tahun } \\
\text { Terbit }\end{array}$} & \multicolumn{1}{|c|}{ Keterangan } \\
\hline Harian Duta Masyarakat & Harian & 1966 & Media Partai NU \\
\hline Harian Mertju Suar & Harian & 1966 & $\begin{array}{l}\text { Media } \\
\text { Muhammadyah }\end{array}$ \\
\hline $\begin{array}{l}\text { Harian Angkatan } \\
\text { Bersenjata }\end{array}$ & Harian & 1966 & $\begin{array}{l}\text { Media Angkatan } \\
\text { Darat/ ABRI }\end{array}$ \\
\hline Harian Suara Karya & Harian & 1966 & Media Partai Golkar \\
\hline Harian Suluh Marhaen & Harian & 1966 & Media Partai PNI \\
\hline Harian Kerakyatan & Harian & 1967 & Media partai PSI \\
\hline Harian Observasi & Harian & 1966 & Media lokal \\
\hline Harian Nusa Putera & Harian & 1970 an & Media lokal \\
\hline Harian Seksama & Harian & 1966 & Media lokal \\
\hline Harian Pontianak Post & Harian & $1960-$ an & Media lokal \\
\hline $\begin{array}{l}\text { Harian Varia Pantai } \\
\text { Utara }\end{array}$ & Harian & 1976 & Media lokal \\
\hline Harian Sutera & Harian & 1970 an & Media lokal \\
\hline Bulletin Kalbar Press & Mingguan & 1970 an & Media lokal \\
\hline Harian Indria & Harian & 1970 an & Media lokal \\
\hline Harian Karya Dharma & Harian & 1970 an & Media lokal \\
\hline
\end{tabular}


Terlihat dari tabel di atas pada awal tahun 1960 -an perkembangan pers di dominasi oleh media - media milik partai. Sedangkan pada tahun 1970 an mediamedia cetak lokal terbentuk sebagai tindak lanjut dari pada perkembangan pers sudah mengarah pada pers yang bersifat komersil. Dalam pengkategorian pers di Indonesia selama ini dipahami ada tiga kategori, yakni pers lokal, regional, dan nasional. Konsep pers lokal merupakan Surat kabar atau Koran yang terbit di daerah tertentu. Artinya, Kantor pusat berlokasi di daerah tersebut dan mayoritas berita yang dimuat adalah berita mengenai daerah tersebut. Surat kabar dengan kategori ini biasanya tidak dapat dibeli di daerah -daerah lain, kecuali berlanganan. Sementara itu, Konsep pers regional lebih mengacu pada Surat kabar yang terbit di Kota (biasanya ibu Kota provinsi) dan disebarkan ke daerah lain yang berada di luar wilayah Kota itu, tetapi tidak ke seluruh negara Indonesia (Hughes, 2001: 11).

Makna yang lebih holistic nampak ketika kita menyebut pers nasional yang bisa berarti Surat kabar yang terbit di daerah tertentu dan disebarkan ke sebagian besar wilayah negara Indonesia Nampak pola kategorisasi dan klasifikasi yang ditawarkan Hunghes lebih ditekankan pada dua hal utama sebagai prinsip dasar. Pertama, posisi geografis tempat Surat kabar bersangkutan diterbitkan atau dicetak (biasanya disebut Kantor pusat). Kedua, pola distribusi yang dilakukan demi keberlangsungan kehidupan Surat kabar bersangkutan. Dalam dua koridor itulah nampaknya sejarah media lokal memiliki dinamika tersendiri. Dalam sejarah pers pada masa orde baru di Pontianak. Tidak hanya media cetak lokal yang berperan akan tetapi media cetak regional juga mengambil andil. Media ini pada umumnya di isi oleh media milik Partai-Partai dan Angkatan Darat.

\section{Media cetak Regional di Pontianak}

Pada tahun 1966 sampai 1970 -an terbitlah beberapa Surat kabar di Pontianak sebagian besar di dominasi oleh partai. Seperti Harian Duta masyarakat Edisi Kalbar, dimana saat itu dipimpin oleh A Syukrie Nour dan M. Sidik Ibrahim. Surat kabar ini merupakan Surat kabar milik partai NU (Nadaratul Ulama) difungsikan sebagai sarana publikasi dan aspirasi partai. Seseorang yang 
menggagas keberadaan Surat kabar tersebut adalah KH A. Wahid Hasyim. Selain sebagai sarana aspirasi partai, tujuan lain dari di terbitkannya Duta Masyarakat adalah sebagai alat propaganda untuk meminimalisir kekuatan pers PKI. Media ini dulu berada di jalan Hos Cokroaminoto (Pasar Mawar Tepatnya).Sebagai Surat kabar yang mewakili NU, suara-suara NU juga melingkupi setiap pemberitaan Duta Masjarakat. Hal ini semakin terlihat jelas tatkala setelah terjadinya peristiwa G-30 S PKI. Setelah terjadinya peristiwa berdarah itu, PKI menjadi sorotan serta bulan-bulanan pemberitaan di semua Surat kabar. Tak terkecuali Duta Masjarakat, yang memang sedari awal mempunyai tujuan untuk menangkal keberadaan PKI. Duta Masjarakat tampil berani dan tegas dalam setiap pemberitaan terkait PKI.

Selain NU Muhammadyah juga memiliki Surat kabar di Pontianak yang diberi Nama Harian Mertju Suar yang pada awal pendiriannya bernama Suara Rakyat. Adapun Pengurus redaksi yang bertanggungjawab ialah selaku Pimpinan Sulaiman Achmad yang dibantu Saleh Badawi. Adapun alamat rekasinya Surat kabar ini berada di Jalan Ir H. Juanda (dulunya). Selain menyampaikan aspirasi organisasi Surat kabar ini juga aktif memberitakan pemberitakan berkenaan tentang pendidikan. Tidak hanya partai ABRI pun Pada tahun 1966 juga memiliki Surat kabar Harian Angkatan Bersenjata namanya. Untuk edisi kalbar Selaku pimpinannya ialah Kapten Piet Damanik dan di bantu oleh Aman S, Ridwan AS, Halim Mahyuddin dan Mawardi Zandyoes. Pada tahun 1967 setahun setelah terbentuk media cetak ini sempat berganti Nama menjadi Harian Dwikora sampai akhinya berubah lagi menjadi Aneka Berita pada tahun 1968. Alamat redaksi di jalan Hos Cokroaminito Area Pasar Mawar Pontianak.

Tidak ketinggalan Partai Nasional Indonesia (PNI) juga ikut andil dalam pendirian Surat kabar di Pontianak seperti partai-partai lainya PNI membentuk Harian Suluh Marhaen. Surat kabar ini muncul sebagai perpanjangan tangan dan alat propaganda dari partai Partai Nasional Indonesia (PNI). Berdiri tahun 1966. Setelah beroprasi selama dua tahun Pada 1968 Surat kabar ini berganti Nama menjadi Kalimantan Membangun. Setelah setahun Partai PNI mendirikan Surat kabar Suluh Marhaen Partai Sosialis Indonesia juga mendirikan Harian Kerakyatan pada tahun 1967. Kerkyatan ini merupakan Surat kabar kebanggaan 
partai tersebut karena semua hal yang dilakukan partai selalu di himpun oleh Surat kabar ini. Adapaun pengurus redaksi Surat kabar ini selaku pimpin oleh Uray Abdul Hamid Machmud dengan dibantu Yakob Bakar BA. Alamat redaksinya berada di Jalan Tanjungpura.

Selanjutnya partai yang sangat berpengaruh pada masa orde baru Golkar memiliki Surat kabar yang diberi Nama Suara Karya. Surat kabar ini berperan sebagai corong propaganda partai. Terbit pada tahun 1970 -an. Pimpinan redaksinya Anang ZA. Surat kabar ini sebelum menjadi harian suara karya bernama Aneka karya. Pada masa orde baru harian suara karya merupakan Surat kabar yang besar karena seperti yang kita ketahui partai Golkar merupakan partai yang paling banyak dimasuki oleh masyarakat sehingga Surat kabar ini memiliki pengarauh yang sangat bersar saat itu.

Dengan alasan menciptakan stabilitas nasional, kekuatan Golkar yang menguasai suara mayoritas di DPR/MPR mendesakkan penyederhanaan partai politik. Sehingga Tahun 1970 "pemerintah" menghimbau agar partai politik itu mengambil langkah-langkah nyata ke arah penyederhanaan sistem kepartaian. Atas dasar himbauan tersebut tahun 1971 di DPR muncul kelompok "Persatuan Pembangunan" yang merupakan wadah kerjasama partai-partai NU, Parmusi, PSII dan Perti yang beraliran "Islam". Juga muncul kelompok "Demokrasi Pembangunan" sebagai tempat bernaung partai-partai PNI, Parkindo, Partai Katolik, IPKI dan Partai Murba yang beraliran "nasional/demokrasi".

Kedua kelompok ini selanjutnya melakukan fusi tahun 1973 sehingga lahir "Partai Persatuan Pembangunan"(PPP) sebagai fusi dari partai-partai politik "Islam" dan "Partai Demokrasi Indonesia"(PDI) sebagai fusi dari partai- partai politik nasional/demokrasi. Dengan demikian, tampil tiga organisasi kekuatan sosial politik yakni PPP, Golkar dan PDI, sebagai infra struktur sistem politik Demokrasi Pancasila di era orde baru.Hal ini diatur dalam Undang-Undang No. 3/1975 tentang Partai Politik dan Golongan Karya (Gau Kadir, 2014: 135). Konsep penyederhanna ini selanjutnya membuat eksistensi dari pada pers partaipartai dengan perlahan terhenti dan mulai membentuk Surat kabar dan para wartawanya banyak membentuk media cetak lokal. 


\section{Media Cetak Lokal Di Pontianak}

Pada tahun 1960 an muncul surat kabar lokal yang terbit di pontinak diantaranya ada ada Pontianak post pimpinan utama pada saat itu M Syaibu Nuralamsyah dan Alwan BM Achmad. Pada tahun 1970 -an surat kabar ini berubah nama menjadi Tropika Post dengan pimpinannya Ya' Agusno Sumantri. Alamat redaksi dari pada Surat kabar ini berada di Jalan Johar. Selanjutnya Observasi merupakan Surat kabar pimpinan M Djunaidi Abas dan sadirman Effendi, berdiri tahun 1966. Observasi merupakan Surat kabar atau Koran yang terbit di Pontianak. Artinya, Kantor pusat berlokasi di Pontianak dan mayoritas berita yang dimuat adalah berita mengenai Pontianak dan sekitarnya. Alamat redaksi berada di jalan Mahakam. Selain Observasi yang merupakan media cetak lokal terbit pula.

Pada tahun 1970 -an Surat kabar di Pontianak banyak sekali bermuncula sebagai salah satu bentuk sarana penyampai informasi dari pemerintah ke masyarakat dan sebaliknya. Diantaranya ada Nusa Putera Surat kabar yang di pimpinan Susani A Is, S Oe Alaydrus dan Bey Akoub ini berdiri pada tahun 1970 an. Alamat redaksi di jalan kapten marssan (Jalan Musi dulunya) No.39 A, tepanya berada di area pasar Kapuas indah. Selanjutnya muncul Surat kabar Seksama yang merupkan Surat kabar yang cukup berani pada masa orde baru. Sempat di berhentikan akibat pemeberitaan yang dilakukannya membuat tersingung pemerintah. Kemudian akibat diberhentikan seksama berubah Nama menjadi Bukittilung dengan pimpinan yang sama Budjang Djamal. Alamat redaksi media cetak ini berada di Jalan Aliayang tepatnya di depan Rumah Sakit Jiwa Aliayang.

Selain seksama yang juga ikut dalam sederetan pers yang kritis ada Varia Pantai Utara merupakan Surat kabar yang ikut mewarnai pers lokal Pontianak. Varia Pantai Utara merupakan Surat kabar indenpenden tidak bergantung dengan Surat kabar lainnya yang ada di Pontianak. Surat kabar ini tidak rutin terbit, bisa seminggu sekali dan bisa juga dua minggu sekali. Pimpinannya pada saat itu Aliman Mochtar. Adapun alamat redaksi Surat kabar ini berada di siantan. Serta 
ada juga Sutera yang merupakan Surat kabar lokal Pontianak berikutnya, yang bertangung jawab menjadi pengurus redaksinya ialah Halim Mahyuddin dan Effendi Asmara Zola. Surat kabar yang berdiri pada tahun 1970 an ini alamat redaksi -nya berada di jalan Juanda. Pada tahun 1980 -an Surat kabar ini merubah namanya menjadi Mandau Post. Selain berkecimpung di Mandau post wartawanwartawan ini juga membentuk Buletin Kalbar Press lahir untuk menetang kesewenagang- wenangan pemerintah pada saat itu. Bulletin yang halamannya hanya dua lembar kertas stensil ini banyak mengekspos berita- berita yang mengkritik pemerintah kala itu. Media cetak yang di prakasai oleh Hery Hanwari A Is dan Efendi Asmara Zola. Alamat Redaksi Di Jalan Aliayang.

Indria merupakan media cetak yang terbit di Pontianak. Surat kabar Indria indentik dengan seseorang bernama S. Soetarman, karena pada saat itu S. Soetarman merupakan pimpinan Redaksi Surat kabar tersebut. Alamat redaksinya berada di jalan Sultan Syarif Abdurahman. Karya Dharma Surat kabar yang terbit tidak teratur bisa harian dan mingguan bahkan bisa sebulan tiga kali terbit. Selaku pimpinan redaksinya R Soeharno. Alamat redaksinya berada di jalan Sultan Syarif Abdurahman. Partisipasi merupakan Surat kabar yang lahir di Pontianak pada tahun 1970 an, dengan pimpinnya Aloysius Djais Patmawidjaja, M Isak Doera dan FB Harsono. Surat kabar ini umumnya terbit setiap minggu. Adapun alamat redaksinya berada di jalan Hasanuddin gg. Bilal (Sungai Jawi).

Pada tahun 1970 -an akhir media cetak di Pontianak terpaksa harus bergabung dikarenakan kondisi pada saat itu tidak memungkinkan media-media tersebut untuk hidup mandiri, dimana harga kertas Koran naik selain itu, mereka harus di bebani dengan biaya produksi. Hal ini di akibatkan oleh minat baca masyarakat yang menurun dan Koran yang tidak banyak terjual. Melihat permasalah yang dihadapi oleh media-media cetak di Pontianak Gubernur ke tiga Kalimantan barat Kol. Kadarusno, mencoba memberikan jalan keluar, caranya berapilisiasi dengan media yang berkekuatan besar serta sanggup menopang masalah yang ada.

Selain memberikan saran untuk berapilisiasi, Gubernur juga membantu menyediakan sebuah percetakan milik pemerintah yang diberi Nama Mandau 
dharma. Mulai beroperasi pada tahun 1970 -an. Percetakan ini Beralamat di jalan Sultan Sarif abdurahman (Nama jalannya sekarang) tepat di depan Jalan Sulawesi. Akan tetapi, bangunan itu sekarang sudah tidak ada lagi hanya terlihat tanah kosong. Dalam menyikapi saran tersebut, tidak semua media menerimanya.

Ada yang menolak untuk bergabung sehingga dengan perlahan mediamedia cetak tersebut harus terhenti penerbitannya (bangkrut) dengan sendirinya, karena tidak mampu menghadapi permasalahan biaya ongkos cetak dan pembayaran wartawan mereka.Selain itu, media cetak di Pontianak hanya menjadikan iklan sebgai sumber pemasukan utama bagi mereka. Ditambah respon negatif masyarakat terhadap pernyataan atau program media cetak, sehingga memicu minat pembaca berkurang.

Dalam kurun waktu 1970 -an ada beberapa media cetak yang menyatakan diri untuk bergabung dengan media cetak lainya. Adapun media cetaknya sebagai berikut. Harian Akcaya gabungan dari media cetak Warta Pemda, Aneka Karya, dan Tropika Post. Selanjutnya Harian Swadaya gabungan dari media cetak Indria, Bebas, dan Karya Dharma. Selain itu, tidak semua media cetak mau ikut bergabung. Banyak media yang enggan bergabung adapun media cetaknya sebagai berikut: Surat Kabar Harian Duta Masyarakat, Harian Mertju Suar, Harian Suara Karya, Nusa Putra, Seksama, Kerakyatan, Varia Pantai Utara, Partisipasi, Hati Nurani, Sutrera, Observasi.alasan media cetak ini tidak bergabung karena mereka merasa pada saat itu tidak mudah mengatur manajemen dari pada media mereka contoh seperti pemberitaan yang harus di tampung oleh media cetak ini akan terbatas, selain itu aka ada pembeludakan wartawan serta pengkatagorian wartawan yang bagus dan kurang bagus. Akhirnya pada saat itu mereka memilih jalan untuk tidak bergabung.

\section{SIMPULAN}

Kesimpulan penelitian menunjukkan sikap pemerintah pada Orde Baru bahwa pemerintah Orde Baru memandang dan memperlakukan pers sebagai Partner of power-nya untuk membantu pemeritah menstabilkan negara, serta alat konsolidasi kekuasaan Presiden Soeharto untuk membangun pemerintahan Orde 
Baru secara penuh (Satrio Saptohadi, 2011:127). Di Pontianak, pemerintah pada masa orde baru juga memperhatikan kesejahteraan lembaga pers saat itu, dengan memberikan subsidi terhadap lembaga pers resmi yang disertai Surat Izin Usaha Penerbitan (SIUP).

Pada masa orde baru, pers di Pontianak bisa dikatakan terbatas dalam menjalankan fungsinya dikarenakan mereka hanya melakukan penyampaian informasi lebih banyak dari pemerintah kepada masyarakat, sedikit penyampaian informasi yang dilakukan dari masyarakat kepada pemerintah, penyampaian informasi itu pun jangan sampai menyinggung pemerintah, apabila pemeritah kurang berkenan dengan pemberitaan maka harus berhati-hatilah media cetak tersebut dan wartawannya. Ada beberapa media cetak baik regional, maupul lokal yang berkembang di Pontianak.

\section{DAFTAR PUSTAKA}

Helius Sjamsudin (2012). Metodologi Sejarah. Yogyakarta: Penerbit Ombak.

Kuntowijoyo (2013). Metodologi Sejarah. Yogyakarta: Penerbit PT. Tiara Wacana Yogya.

Syahriar, Irma. (2015). Hukum Pers: Telaah Teoristis atas Kepastian Hukun dan Kemerdekaan Pers di Indonesia. Yogyakarta: Penerbit Laksbang Pressindo.

Trianton, Teguh. (2016). Jurnalistik Komprehensif. Yogyakarta: Penerbit Ombak.

Hughes, Kirrilee. Wajah Pers Malang. Laporan Studi lapangan. Universitas Muhammadiyah Malang bekerjasama dengan Australian Consortium for in- Country Indonesia Studies. 2001.

A.W. Kaligis, Retor. (2011). Peranan Pers Dalam Penyebaran Kesadaran Nasional. Jounal of Insani. Vol. 1, No. 11, 83- 90.

Dwi Wahyono Hadi dan Gayung Kasuma. Propaganda Orde Baru 1966-1980. (2012). Journal of Verleden Vol. 1, No.1, 1-109.

Hapsari, Sinung Utami Hasri. (2012). Hukum Media, Dulu, Kini Dan Esok. Journal of Riptek Vol. 6, No.1, 9-24.

Kadir, A. Gau. (2014). Dinamika Partai Politik Di Indonesia. Jounal of Sosiohumaniora. Vol. 16, No. 2, 132 - 136. 
Sulhan, Muhammad. (2006). Kisah Kelabu di Balik Maraknya Pers Lokal di Kalimantan. Journal of Imu Sosial dan Ilmu Politik. Vol. 9, No. 3, 317335. 